\title{
COVID-19 and ECMO: the interplay between coagulation and inflammation-a narrative review
}

\author{
Mariusz Kowalewski ${ }^{1,2,3^{*}+}$ (D), Dario Fina ${ }^{2,4 \dagger}$, Artur Słomka ${ }^{5}$, Giuseppe Maria Raffa ${ }^{6}$, Gennaro Martucci ${ }^{7}$, \\ Valeria Lo Coco ${ }^{2,6}$, Maria Elena De Piero ${ }^{2,8}$, Marco Ranucci ${ }^{4}$, Piotr Suwalski ${ }^{1}$ and Roberto Lorusso ${ }^{2,9}$
}

\begin{abstract}
Infection with severe acute respiratory syndrome coronavirus 2 (SARS-CoV-2) has presently become a rapidly spreading and devastating global pandemic. Veno-venous extracorporeal membrane oxygenation (V-V ECMO) may serve as life-saving rescue therapy for refractory respiratory failure in the setting of acute respiratory compromise such as that induced by SARS-CoV-2. While still little is known on the true efficacy of ECMO in this setting, the natural resemblance of seasonal influenza's characteristics with respect to acute onset, initial symptoms, and some complications prompt to ECMO implantation in most severe, pulmonary decompensated patients. The present review summarizes the evidence on ECMO management of severe ARDS in light of recent COVID-19 pandemic, at the same time focusing on differences and similarities between SARS-CoV-2 and ECMO in terms of hematological and inflammatory interplay when these two settings merge.
\end{abstract}

\section{SARS-CoV-2 and COVID-19}

COVID-19 is a disease caused by the novel SARS-CoV-2 virus which appeared in December 2019 and is now a worldwide pandemic [1]. Although most COVID-19 patients have moderate symptoms and recover quickly, some patients develop severe respiratory failure requiring intensive care unit (ICU) admission and, often, mechanical ventilation [2].

SARS-CoV-2 enters target cells via the angiotensinconverting enzyme 2 (ACE2) by a receptor-mediated endocytosis [3]. ACE2 is a type I integral membrane protein with several physiologic functions, well expressed in the lungs (overexpressed in smokers), heart, kidney, and

\footnotetext{
*Correspondence: kowalewskimariusz@gazeta.pl

${ }^{\dagger}$ Mariusz Kowalewski and Dario Fina contributed equally to this work. ${ }^{1}$ Clinical Department of Cardiac Surgery, Central Clinical Hospital of the Ministry of Interior and Administration, Centre of Postgraduate Medical Education, Wołoska 137 Str, 02-507 Warsaw, Poland

${ }^{2}$ Cardio-Thoracic Surgery Department Heart and Vascular Centre, Maastricht University Medical Centre, Maastricht, the Netherlands

Full list of author information is available at the end of the article
}

gastrointestinal tract. Through the renin-angiotensin system (RAS), the virus may impact the lung circulation, but the expression on the endothelium may lead to its activation and further systemic damage with a prothrombotic state. The variable involvement of the endothelium, as well as other key organs (the liver as first), may explain the heterogeneity of the clinical picture. But as much as now is evident by the shared reports worldwide, the prothrombotic state is common in non-survivors of COVID-19 [4].

Beyond ventilator support, as well as support of other organ failures (the liver, kidney, and heart frequently involved), several drugs (antivirals, antimalaric, antibiotics, and drugs active on specific inflammatory pathways) are currently being tested but consensus or recommendations for any antiviral drug or drug combination is still lacking [3]. Several therapeutic strategies are proven to be partially ineffective, even burdened by relevant too many side effects. In the current limited health resources scenario, it would be important to adopt any adjuvant therapies that may contribute to a better outcome, but

(c) The Author(s). 2020 Open Access This article is licensed under a Creative Commons Attribution 4.0 International License, which permits use, sharing, adaptation, distribution and reproduction in any medium or format, as long as you give appropriate credit to the original author(s) and the source, provide a link to the Creative Commons licence, and indicate if changes were made. The images or other third party material in this article are included in the article's Creative Commons licence, unless indicated otherwise in a credit line to the material. If material is not included in the article's Creative Commons licence and your intended use is not permitted by statutory regulation or exceeds the permitted use, you will need to obtain permission directly from the copyright holder. To view a copy of this licence, visit http://creativecommons.org/licenses/by/4.0/ The Creative Commons Public Domain Dedication waiver (http://creativecommons.org/publicdomain/zero/1.0/) applies to the data made available in this article, unless otherwise stated in a credit line to the data. 
considering the impact on inflammation of the large extracorporeal surface in contact with the blood, several specific considerations should be made on the coagulation profile of the single patient [5].

\section{COVID-related severe respiratory impairment and V-V ECMO}

The mortality in COVID-19 patients who develop severe respiratory compromise and require mechanical ventilation is high [3]. The above is of particular importance given the potential accessibility to veno-venous extracorporeal membrane oxygenation (V-V ECMO) since it may serve as life-saving rescue therapy. While still little is known on the true efficacy of ECMO in the COVID19 setting, the natural resemblance of seasonal influenza's complications with respect to acute onset and symptoms prompt to ECMO implantation in most severe, pulmonary decompensated patients.

The first scenario (Fig. 1) in which ECMO may be indicated in COVID-19 patients is a severe pneumonia with acute respiratory compromise refractory to optimal conventional management including standard lung-protective ventilation strategy, prone positioning, neuromuscular blockade, and volume optimalization [6-8]. In this particular case, a V-V ECMO is indicated and the criteria to follow for its implantation are $\mathrm{PaO} 2 / \mathrm{FiO} 2<100 \mathrm{mmHg}$ and/or arterial blood $\mathrm{PH}<7.2$ and $\mathrm{PaCO} 2>60 \mathrm{mmHg}$ [9]. Additional parameters to take into account may be mechanical ventilation $<7$ days, age $<65$ years old, ventilator frequency $<35$ breath per minute (bpm), and plateau pressure $>30 \mathrm{~cm} \mathrm{H}_{2} \mathrm{O}$ [10]. Some studies showed that an early use of $\mathrm{V}-\mathrm{V}$ ECMO in respiratory distress may minimize respiratory-driven pressure and reduce pulmonary and systemic inflammation as well as severe multiorgan dysfunction $[11,12]$. Therefore, V-V ECMO is a feasible option in COVID patients not responding to conventional interventions resulting in improved outcome and lung protection [13].

Another possible scenario is a severe myocarditis (Fig. 1) which may evolve in a cardiac dysfunction. In addition, the virus can also exacerbate comorbidities leading to ischemic heart failure as well as precipitate sepsis-related cardiomyopathy or frank septic shock-related situation. All of these conditions may need a veno-arterial (V-A ECMO) implanted as primary support $[14,15]$.

ECMO management is complex and dynamic according to the onset of complications and pathological events. In that way, a V-V ECMO in COVID-19 patients may also be complicated by septic and cardiogenic shock with refractory multi-organ failure as well as cardiac arrhythmias which may need an adjustment in the primary configuration [16]. In such condition, optimal biventricular unloading with concomitant high-flow ECMO support as well as partial lung perfusion with oxygenated blood may be required and achieved by adding an extra

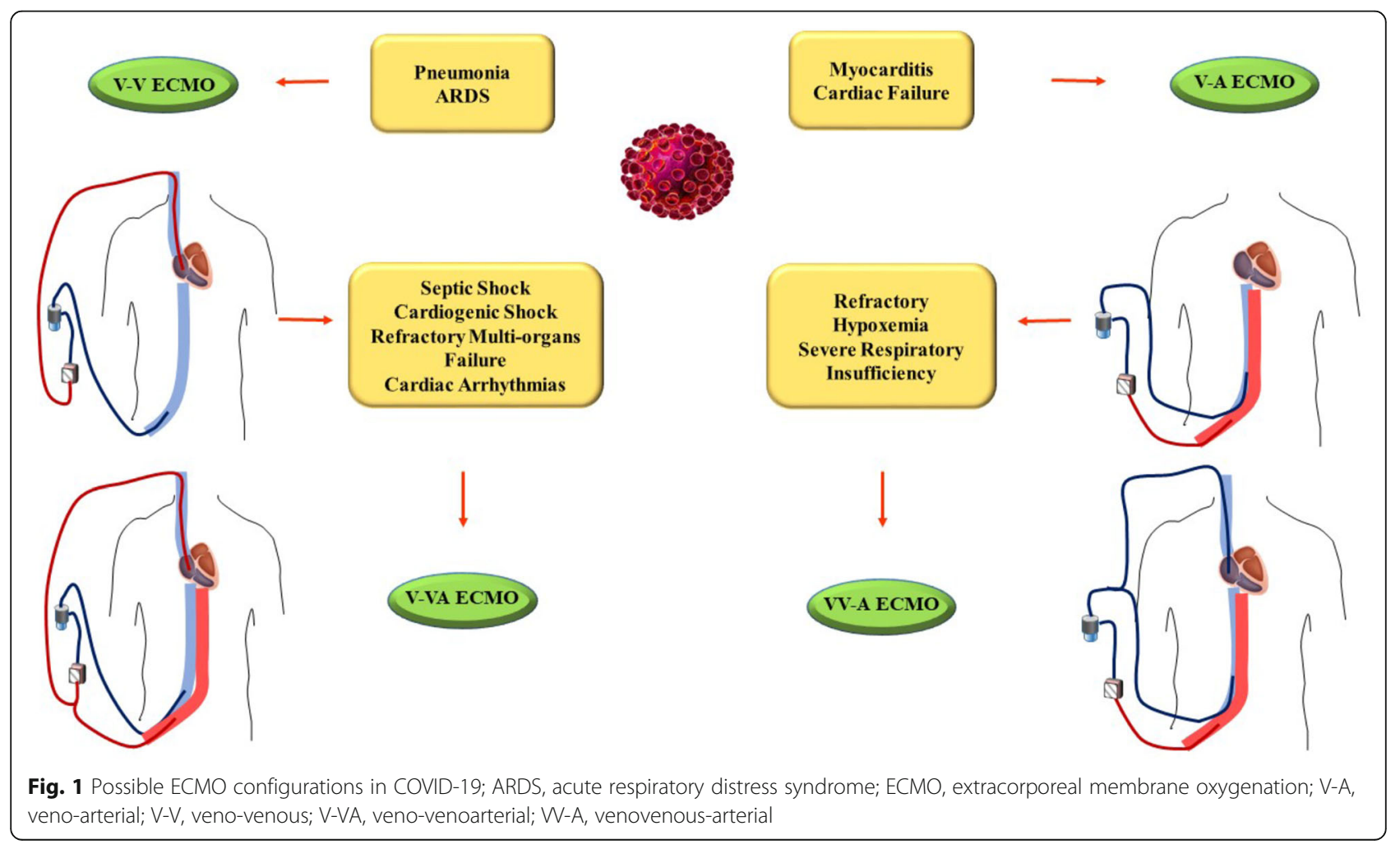


outflow cannula resulting in a veno-venoarterial (V-VA) ECMO. A hybrid ECMO may also be required when the V-A ECMO is the first approach for the development of a severe respiratory insufficiency with refractory hypoxemia. This condition may be solved with the implementation of an extra inflow cannula to improve the oxygenation (higher drainage and thus higher perfusion flow) and the metabolic needs resulting in a venovenous-arterial (VV-A) ECMO. Other situations that may require configuration alterations are the development of site- or access-related complications (i.e., bleeding of the vascular site or differential oxygenation respectively).

In COVID-19 patients, ECMO may represent an efficient support in case of severe and refractory respiratory dysfunction and/or cardiogenic/septic shock unresponsive to maximal therapy. Yet available reports focusing on respiratory compromise treatment in COVID-19 patients, and in particular, those undergoing V-V ECMO therapy however are very restrained in declaring ECMO benefit [3]. It has become evident from the published evidence that SARS-CoV-2 infection itself promotes immunological response unseen with seasonal influenza [17]; similarly, changes observed in hematological and coagulation characteristics of affected patients differ from those observed in seasonal flu infections; on top of ECMO therapy, this may, in turn, lead to unpredictable physiopathological changes in both immune and hemostatic systems, complicating the course of disease.

\section{Cytokine storm}

Cytokine storm syndrome [18] is a hyperinflammatory state that is characterized by fulminant multi-organ failure and elevation of cytokine levels. The underlying pathophysiology of inflammatory disease may result in pulmonary, cardio-circulatory, or combined disturbances with vasodilatation and membrane leakage, which can ultimately lead to severe vasoplegic shock difficult to control. At the same time, during ECMO, the large and continuous contact surface between the humoral and cellular components of the blood and the extracorporeal circuit causes a systemic activation of coagulation and inflammation pathways that, in extreme conditions, may lead to thrombosis and disseminated intravascular coagulation [5]. The two principal mechanisms of activation of coagulation are supraphysiological shear stress and interactions between the foreign material and blood components [19-22]. The latter creates an inflammatory reaction, as already reported in the systemic inflammatory response syndrome, that involves leukocytes, platelet endothelial cells, intrinsic and extrinsic coagulation, cytokines, and complement system [23]. The result is an unbalance between pro-coagulant and anticoagulant factors, e.g., fibrinogen contributes to thrombus formation, while loss of high molecular vWF causes a bleeding tendency [24].

Infection triggers a complex host response, in which pro-inflammatory and anti-inflammatory mechanisms may contribute to the clearance of infection and tissue recovery, as well as to organ injury and secondary infections [25]. The immune reaction depends on the patient's individual condition, coexisting diseases, and the specific load and pathogenicity of the causative agent $[26,27]$. A recent study showed that COVID-19 is associated with a cytokine elevation profile that is reminiscent of secondary hemophagocytic lymphohistiocytosis [28]. All these observations may justify a wide activation of coagulation through inflammatory pathways, with a direct clinical warning about thrombosis and circuit consumption which availability and sparing may become critical during a pandemic burden.

Finally, as much of the coagulation components play a double role also in innate immunity and inflammation, also thrombin (activated factor II) is a crucial procoagulant protease able to initiate thromboembolic and pro-inflammatory responses [20]. In the continuous endothelial activation, antithrombin (AT) plays a relevant role, since it is more exposed on the endothelium when the cells are activated, and it is more released in the blood with consequent relatively rapid consumption in case of use of high doses of heparin [29].

The pathogenesis of COVID-19 is still under the hypothesis, but if the endothelial activation is crucial, as supposed by the presence of ACE2 on the endothelial surface, AT, as well as heparin and generally anticoagulation, may play a relevant role in reducing the inflammation and potentially mortality. Indeed, the interaction of AT with heparin-like GAGs on the endothelial cell surface involves the release of prostacyclin, which inhibits leukocyte activation by decreased release of IL-6, IL-8, and tumor necrosis factor (TNF) [30]. All these appear to be elevated during COVID-19 and it is cytokine storm that is seen at the beginning of the disease. Ruan et al. [31] and Zhou et al. [32] have identified a high level of IL- 6 as a potential predictor of fatal outcome when compared between survivors and patients who died of COVID-19 disease. IL-6 is well known being linked to the trans-signaling pathway, which causes vascular leakage [33], the first step of a cascade followed by tissue edema, hypoxia, and finally necrosis. In this scenario, hemoadsorption therapy may be used to decrease cytokine levels in case of excessive inflammatory response and due to its unspecific adsorptive characteristics also substances like myoglobin, free hemoglobin, or bilirubin. Trager et al. [34] report successful treatment of septic shock and a severe SIRS response with pronounced hypercytokinemia with a combination of cytokine reduction and inflammation reduction with CytoSorb, VA-ECMO, renal support 
with continuous renal replacement therapy (CRRT) and low-dose hydrocortisone [35]. It seems that controlling pro-inflammatory response may be advantageous for the maintenance of the vascular barrier function, which plays a pivotal role in the development of tissue edema and oxygen mismatch.

Hemoadsorption and also other blood purification techniques can be used as stand-alone or in combination with extracorporeal circuits [25]. CRRT and ECMO yet still no sound recommendation for clinical use are made in the management of sepsis and septic shock because high-class evidence is lacking [27]. COVID-19 mortality [3] might be due to virus-activated cytokine storm syndrome, and for this reason, a novel device for adsorbing inflammatory and other mediators from the circulation seems to offer a promising approach. Tocilizumab, a monoclonal antibody against IL-6, recently emerged as an alternative treatment for COVID-19 patients with a documented or cytokine storm [36]. Reports and singlecenter experiences $[37,38]$ have been documented and its actual efficacy is going to be assessed by dedicated investigations [NCT04317092].

\section{Laboratory disorders in SARS-CoV-2 infection vs V-V ECMO}

Table 1 lists the major laboratory changes observed both during ECMO therapy and COVID-19 infection. Of importance is the multiplication of alterations induced by these V-V ECMO circuits caused by SARS-CoV-2 infection. Of particular importance are the fluctuations in hematological, biochemical, and coagulation level characteristics.

Analysis of the available literature shows that thrombocytopenia in patients infected with SARS$\mathrm{CoV}-2$ is a relatively rare phenomenon $[16,39-41]$. Nevertheless, the biggest study to date, which included 1099 COVID-19 patients, showed that those treated in intensive care units had a reduced platelet count [3]. In a study underlining differences of coagulation features between severe pneumonia induced by SARS-CoV-2 and non-SARS-CoV-2, the platelet count of the COVID group was significantly higher than that of non-COVID patients [42]. A role of the increased thrombopoietin levels following pulmonary inflammation has been proposed, exacerbating more severe inflammation reaction and hypercoagulability. Platelets are produced by megakaryocytes in the bone marrow, and a variety of cytokines, including IL3, IL6, IL-9, and IL-11, are able to trigger their production [43]. Moreover, clinical and experimental evidence indicates that platelets are a source of microvesicles with a strong pro-inflammatory potential. On the other hand, some authors have shown that platelets increased first and then decreased in severe COVID patients during the hospital stay and therefore speculated that the changes in platelets in the treatment course may correlate with the progression and prognosis of COVID-19 [44]. The relationship between the low number of platelets and the severity of the disease was also reported in a meta-analysis of 9 studies of 1779 patients [45]. Again, patients with severe disease had a lower platelet count [46]. In addition, determination of platelet counts is recommended for all patients in light of the published International Society on Thrombosis and Haemostasis (ISTH) guidelines [47]. It should be stressed, however, that platelet monitoring should be combined in clinical practice with an assessment of their functioning. Unfortunately, the current data do not allow conclusions on this issue. Thrombocytopenia, on the other hand, is one of the many complications of ECMO [48-50]. It is estimated that approximately 1 in 5 patients may experience severe thrombocytopenia (platelets $<50 \times 109 / \mathrm{L}$ ) [48]. This complication appears to increase with the duration of ECMO; however, the mechanism of thrombocytopenia is not as simple as it initially appears. Abrams et al. [50] showed that low platelet count is not related to the duration of ECMO, but rather to platelet count and disease severity at the time of cannulation. In the pathogenesis of thrombocytopenia during ECMO, the possibility of heparin-induced thrombocytopenia (HIT) should also be considered [51]. Interestingly, patients with HIT on VA-ECMO are characterized by much more severe thrombocytopenia compared to VV-ECMO [51]. In addition, the severity of this complication may depend on the system used in ECMO-Priming Reduced Extracorporeal Circulation Setup (PRECiSe) patients have lower platelet count than minimal extracorporeal circuit (MECC) cases [52]. Functional analysis of platelets also shows that platelet activation depends on a factor stimulating this process [52].

It is widely acknowledged that the majority of COVID-19 patients, especially those with severe disease, are characterized by lymphocytopenia. This laboratory symptom is observed mostly in adult patients, much less often to children [45], and may predict COVID-19 severity [53]. The second important remark is that the reduced number of lymphocytes is also a common feature of diseases caused by other coronaviruses, including SARS [54] and MERS [55]. Notably, the currently available data strongly indicates that lymphocytopenia is dynamically modulated by the intensification of local and systemic inflammation, direct infection of lymphocytes, and destruction of lymphoid organs $[55,56]$. In addition, treatment with glucocorticosteroids may cause lymphocytopenia in some cases [57]. 
Table 1 Comparison of hematological and biochemical parameters in V-V ECMO and SARS-CoV-2 induced ARDS
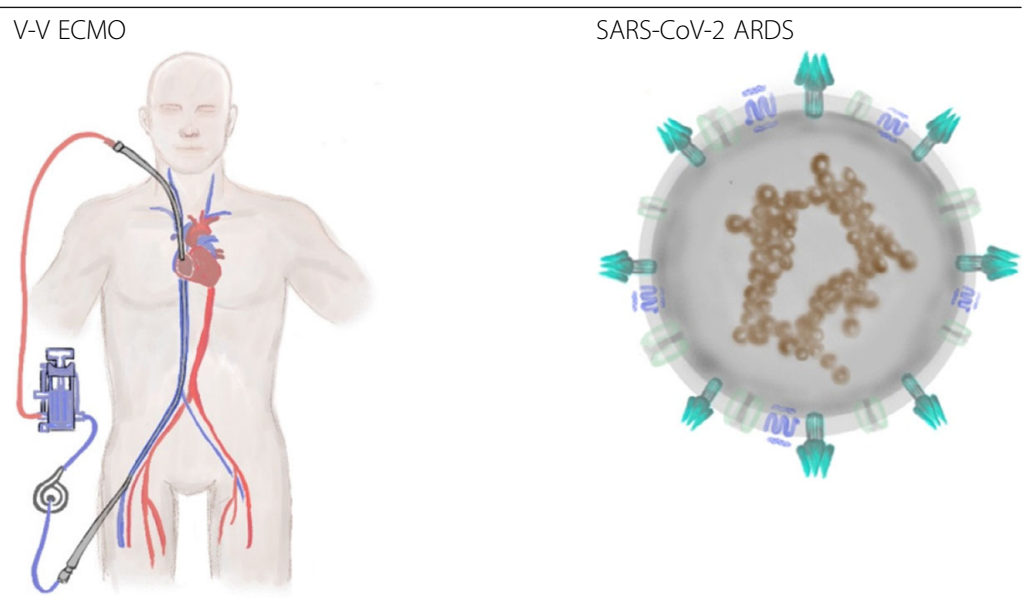

\section{Hematological findings}

White blood cell count

Lymphocyte

Neutrophil

Neutrophil activation

Monocyte

$\mathrm{CD}^{+}, \mathrm{CD}^{+}, \mathrm{CD}^{+}, \mathrm{T}$ cells

Natural killer cells

Neutrophil to lymphocyte ratio

Hemoglobin and red blood cell count

Platelet count

Initial $\uparrow$

$\downarrow$

Initial $\uparrow \quad \uparrow$

Initial $\uparrow$

Initial $\uparrow$ -

$\downarrow$

$\downarrow$

$\downarrow \downarrow$

$-\downarrow$

$\uparrow$

$\downarrow$

\section{Coagulation and anticoagulation}

Platelet activation

Platelet aggregation

Platelet activation factor

Heparin-induced thrombocytopenia

Von Willebrand factor

D-dimer

Fibrin degradation products

Activated partial thromboplastin time

Prothrombin time

Thrombospondin

Fibronectin

Thrombin

Fibrinogen

High molecular weight kininogen

Prekallikrein

Kallikrein

FVIII

FX

$\mathrm{FXI}$

FXla

FXII

$\begin{array}{ll}\uparrow & ? \\ \downarrow & ? \\ \uparrow & ? \\ \uparrow & ? \\ \downarrow & ? \\ \uparrow & \uparrow \\ \uparrow & \uparrow \\ \uparrow & \text { ? } \\ \downarrow & - \\ \downarrow & ? \\ \uparrow & ? \\ \text { Initial } \downarrow & ? \\ \uparrow & ? \\ \downarrow & \uparrow \\ \uparrow & ? \\ \downarrow & ? \\ \uparrow & ? \\ \downarrow & ? \\ \uparrow & ? \\ \downarrow & ? \\ & ? \\ & ? \\ & ? \\ & ?\end{array}$


Table 1 Comparison of hematological and biochemical parameters in V-V ECMO and SARS-CoV-2 induced ARDS (Continued)

\begin{tabular}{|c|c|c|}
\hline FXIla & Rapid $\uparrow$ & $?$ \\
\hline FXIII & $\downarrow$ & $?$ \\
\hline Antithrombin & Initially $\downarrow$ (UFH) & $\downarrow$ \\
\hline C-protein & $\uparrow \downarrow$ & $?$ \\
\hline Activated clotting time & $\uparrow$ & $?$ \\
\hline R-time thromboelastography & $\uparrow$ & $?$ \\
\hline \multicolumn{3}{|l|}{ Inflammatory response } \\
\hline Tissue factor & $\uparrow-$ & $?$ \\
\hline Bradykinin & $\uparrow$ & $?$ \\
\hline TNF-alpha & $\uparrow$ & $-\uparrow$ \\
\hline IFN-gamma & $?$ & $\uparrow$ (4-6 days after presentation) \\
\hline IL-1-beta & $\uparrow$ & $\downarrow \downarrow$ \\
\hline $\mid \mathrm{L}-2$ & $?$ & $\begin{array}{l}\uparrow \\
4-6 \text { days after presentation }\end{array}$ \\
\hline $\mathrm{IL}-2 \mathrm{R}$ & $?$ & $\uparrow$ \\
\hline IL-4 & $?$ & - \\
\hline IL-6 & $\uparrow$ & $\uparrow \uparrow$ \\
\hline$\| \mathrm{L}-8$ & $\uparrow$ & $?$ \\
\hline IL-10 & $\uparrow$ & $\uparrow$ \\
\hline $\lg E$ & $\downarrow$ & $?$ \\
\hline $\lg A$ & $?$ & - \\
\hline $\lg G$ & $?$ & $-\uparrow$ \\
\hline $\lg M$ & $?$ & - \\
\hline Complement & $-\uparrow$ & - \\
\hline
\end{tabular}

UFH unfractionated heparin

The references to support the above table are listed as supplementary S1-S82

Coagulopathies of diverse etiologies were described in COVID-19 patients; of importance is the augmented risk of venous thromboembolism (VTE). Though there are no published case series thus far, there exist reports of abnormal coagulation parameters in hospitalized patients with severe COVID-19 disease. In a multicenter retrospective cohort study from China, elevated D-dimer levels $(>1 \mathrm{~g} / \mathrm{L})$ were strongly associated with in-hospital death, even after multivariable adjustment (OR 18.4, 95\% CI 2.6-128.6; $p=0.003$ ) [32]. In the cohort study by $\mathrm{Wu}$ et al. [58] involving 201 patients with confirmed COVID-19 pneumonia, risk factors associated with the development of ARDS and progression from ARDS to death included among others coagulation dysfunction. For patients with ARDS who died, coagulation function indices (D-dimer [difference, $2.10 \mu \mathrm{g} / \mathrm{mL} ; 95 \% \mathrm{CI}$, $0.89-5.27 \mu \mathrm{g} / \mathrm{mL} ; \quad p=0.001])$ were significantly elevated compared with patients with ARDS who survived; elevated $\mathrm{D}$-dimers were elevated and prognostic of worse outcome in other reports as well. In another study comparing COVID-19 survivors to nonsurvivors, non-survivors had significantly higher Ddimer and fibrin degradation product (FDP) levels and $71.4 \%$ of non-survivors met clinical criteria for disseminated intravascular coagulation (DIC) during the course of their disease [17].

Other laboratory parameters for the routine assessment of blood coagulation appear to be normal in COVID-19 patients regardless of the severity of infection, except for a single case of prolonged prothrombin time (PT) [39] and reduced activated partial thromboplastin time (aPTT) [59] in severe SARS-CoV-2-infected cases.

While the optimal anticoagulation regimens to prevent VTE and DIC in the setting of critically ill, immobilized COVID-19 patients remain unknown, V-V ECMO is a double-edged sword; on one side, it promotes thrombosis and hypercoagulable state; on the other, ECMO circuits are eliminating coagulation factors binding them irreversibly to surface coating material. In fact, iv. administered unfractionated heparin (UFH) which is required for the ECMO run [60] is further aggravating anticoagulatory state by interplaying with antithrombin on many levels. Anti-inflammatory functions of AT are partly mediated through inhibition of thrombin that reduces platelet activation, neutrophil-endothelial cell interactions, and endothelial upregulations [25]. In 
patients on ECMO, acquired AT deficiency is a result of hemodilution, blood coagulation activation, and consumption due to the use of UFH [61]. The binding of AT to UFH competes with the binding of AT to endothelial GAGs, thus increasing the likelihood of inflammation-related complications. In this light, low levels of AT can increase the risk of either thrombotic or hemorrhagic complications, the first because of the reduced effect of heparin, and the second due to relevant concomitant inflammatory response, organ damage, and concomitant coagulation factor consumption [30, 6264]. While several authors have reported a relevant reduction in mortality with higher dosage of heparin in COVID-19, it is too early to gather definitive conclusions but a deep attention to the coagulation profile during ECMO should be considered. As a desired positive "side effect" of ECMO support, the use of high-dosage anticoagulation as well as an attitude to a thorough coagulation profile study may contribute to a better outcome in COVID-19.

\section{Evidence summary of available reports on COVID- 19 and ECMO}

Table 2 summarizes the outcomes gathered from experiences with ECMO in COVID-19; a database search for valid records was conducted according to PRISMA guidelines until April 5; keywords used were ECLS, ECMO, COVID-19, and SARS-CoV-2; studies mentioning ECMO treatment in COVID-19 were included; case reports were not considered. Eleven studies were included [3,16, 17, 31, 32, 39, 58, 65-68]. Potential overlap of patient populations cannot be excluded. Of 2884 COVID-19 patients, 440 (15.5\%) developed ARDS and $401(14.1 \%)$ were transferred to ICU; forty-two patients $(1.5 \%)$ were treated with ECMO; in an overall cohort, observed mortality was 273 (9.6\%). Outcome data of ECMO patients are incomplete with regard to ECMO configurations, duration, and indication. Shen et al. [67] demonstrated favorable outcome in case series of 5 critically ill patients, one of which had ECMO implanted and was successfully weaned 5 days after transfusion of convalescent plasma with a SARS-CoV-2-specific antibody. On the other hand, in the study by Yang et al. [68] who compared clinical characteristics and outcomes in patients with severe COVID-19, five (83\%) of six patients receiving ECMO died. Ruan et al. [31] and Zhou et al. [32] reported $100 \%$ mortality for ECMO patients. Although these samples were small, and specific baseline characteristics and disease courses were almost unknown, the studies raise concerns about potential harms of ECMO therapy for COVID-19. This is, indeed, further reflected in guideline recommendations; "Clinical management of severe acute respiratory infection when Novel coronavirus (nCoV) infection is suspected" Interim Guidance document by WHO recommends to "consider referral patients with refractory hypoxemia

Table 2 The outcomes gathered from experiences with ECMO in COVID-19

\begin{tabular}{|c|c|c|c|c|c|c|c|c|}
\hline Study & Type & Location & N & ICU admission & ARDS & ECMO & $\begin{array}{l}\text { Overall } \\
\text { mortality }\end{array}$ & $\begin{array}{l}\text { ECMO } \\
\text { mortality }\end{array}$ \\
\hline Chen et al. [65] & $\begin{array}{l}\text { Retrospective } \\
\text { observational }\end{array}$ & Wuhan Jinyintan Hospital & 99 & $23(23.2 \%)$ & $17(17.2 \%)$ & $3(3.0 \%)$ & $11(11.1 \%)$ & NA \\
\hline Guan et al. [3] & Cross-sectional & $\begin{array}{l}552 \text { hospitals in } 30 \text { provinces, } \\
\text { autonomous regions, and } \\
\text { municipalities in mainland China }\end{array}$ & 1099 & $55(5.0 \%)$ & $37(3.4 \%)$ & $5(0.5 \%)$ & $15(1.4 \%)$ & NA \\
\hline Huang et al. [39] & Cross-sectional & Jin Yin-tan Hospital, Wuhan, China & 41 & $13(31.7 \%)$ & $12(29.3 \%)$ & $2(4.9 \%)$ & $6(14.6 \%)$ & NA \\
\hline Liu et al. [66] & $\begin{array}{l}\text { Retrospective } \\
\text { observational }\end{array}$ & Nine tertiary hospitals in Hubei & 137 & NA & $34(24.8 \%)^{*}$ & $0(0.0 \%)$ & $16(11.7 \%)$ & NA \\
\hline Ruan et al. [31] & $\begin{array}{l}\text { Retrospective } \\
\text { multicenter study }\end{array}$ & $\begin{array}{l}\text { Jin Yin-tan Hospital and Tongji } \\
\text { Hospital }\end{array}$ & 150 & $41(27.3 \%)$ & $62(41.3 \%)$ & $7(4.7 \%)$ & $68(45.3 \%)$ & $7(100 \%)$ \\
\hline Shen et al. [67] & Case series & $\begin{array}{l}\text { Shenzhen Third People's } \\
\text { Hospital in Shenzhen, China }\end{array}$ & 5 & $5(100 \%)$ & $5(100 \%)$ & $1(20.0 \%)$ & $0(0.0 \%)$ & $0(0.0 \%)$ \\
\hline Tang et al. [17] & $\begin{array}{l}\text { Retrospective case- } \\
\text { control study }\end{array}$ & Wuhan Pulmonary Hospital & 73 & $73(100 \%)$ & $73(100 \%)$ & $10(13.7 \%)$ & $21(28.3 \%)$ & NA \\
\hline Wang et al. [16] & Case series & $\begin{array}{l}\text { Zhongnan Hospital of Wuhan } \\
\text { University in Wuhan, China }\end{array}$ & 138 & $36(26.1 \%)$ & $22(15.9 \%)$ & $4(2.9 \%)$ & $6(4.3 \%)$ & NA \\
\hline Wu et al. [58] & $\begin{array}{l}\text { Retrospective } \\
\text { cohort study }\end{array}$ & Wuhan Jinyintan Hospital & 201 & $53(26.4 \%)$ & $84(41.8 \%)$ & $1(0.5 \%)$ & $44(21.9 \%)$ & NA \\
\hline Yang et al. [68] & $\begin{array}{l}\text { Retrospective } \\
\text { observational }\end{array}$ & $\begin{array}{l}\text { Wuhan Jin Yin-tan hospital } \\
\text { (Wuhan, China) }\end{array}$ & 710 & $52(7.3 \%)$ & $35(4.9 \%)$ & $6(0.8 \%)$ & $32(4.5 \%)$ & $5(83.3 \%)$ \\
\hline Zhou et al. [32] & $\begin{array}{l}\text { Retrospective } \\
\text { cohort study }\end{array}$ & $\begin{array}{l}\text { Jinyintan Hospital and Wuhan } \\
\text { Pulmonary Hospital }\end{array}$ & 191 & $50(26.2 \%)$ & 59 (30.9\%) & $3(1.6 \%)$ & $54(28.3 \%)$ & $3(100.0 \%)$ \\
\hline
\end{tabular}


despite lung-protective ventilation in settings with access to expertise in ECLS" [69]. Similarly, the United States Center for Disease Control provides interim guidance for clinical management of COVID-19 patients with and without ARDS: "Where ECLS expertise is available, ECLS should be considered according to the standard management algorithm for ARDS in supporting patients with viral lower respiratory tract infection" [70]. However, clearly, at this time, there is little worldwide experience with using ECLS to support COVID-19 patients; ELSO leaders have discussed the potential role of ECMO for COVID-19 patients in a recent JAMA Viewpoint [71] stating that ECMO is not a therapy to be rushed to the frontline when all resources are stretched in a pandemic and pointing to problems with proper ECMO referral and management in centers less well experienced in these therapies. Support with ECMO is further not available in many low- and middle-income countries; therefore, ECMO might not seem to gain as much of a priority as personal protective equipment, correct management, diagnosis and quarantine, oxygen therapy alone, and mechanical ventilation in first stance [72].

Finally, ELSO will continue to collect data through member centers through the ELSO Registry and provide recommendations as additional information becomes available from ongoing studies [73].

\section{Conclusions}

Because ECMO therapy and COVID-19 itself are associated with certain, often synergistic changes in hematological and inflammatory status of the patients, the efficacy of ECMO is largely dependent on centers' experience with such therapies.

\section{Supplementary information}

Supplementary information accompanies this paper at https://doi.org/10. 1186/s13054-020-02925-3.

Additional file 1. Supplementary references.

\section{Acknowledgements}

None.

\section{Authors' contributions}

The author(s) read and approved the final manuscript.

\section{Funding}

None.

\section{Availability of data and materials}

All data generated or analyzed during this study are included in this published article [and its supplementary information files].

\section{Ethics approval and consent to participate} Not applicable.

Consent for publication

Not applicable.

\section{Competing interests}

None

\section{Author details}

${ }^{1}$ Clinical Department of Cardiac Surgery, Central Clinical Hospital of the Ministry of Interior and Administration, Centre of Postgraduate Medical

Education, Wołoska 137 Str, 02-507 Warsaw, Poland. ${ }^{2}$ Cardio-Thoracic Surgery Department Heart and Vascular Centre, Maastricht University Medical Centre, Maastricht, the Netherlands. ${ }^{3}$ Thoracic Research Centre Collegium Medicum, Nicolaus Copernicus University, Innovative Medical Forum, Bydgoszcz, Poland. ${ }^{4}$ Department of Cardiovascular Anesthesia and ICU, IRCCS Policlinico San Donato, Milan, Italy. ${ }^{5}$ Chair and Department of Pathophysiology Nicolaus Copernicus University, Collegium Medicum, Bydgoszcz, Poland. ${ }^{6}$ Cardiac Surgery Unit, IRCCS-ISMETT, Palermo, Italy. ${ }^{7}$ Anesthesia and Intensive Care Department, IRCCS-ISMETT, Palermo, Italy. ${ }^{8}$ Department of

Anesthesia-Intensive Care San Giovani Bosco Hospital, Turin, Italy.

${ }^{9}$ Cardiovascular Research Institute Maastricht (CARIM)I, Maastricht, the Netherlands.

Received: 13 April 2020 Accepted: 27 April 2020

Published online: 08 May 2020

\section{References}

1. https://www.who.int/csr/don/12-january-2020-novel-coronavirus-china/en. Accessed 3 Apr 2020.

2. Zhou G, Chen S, Chen Z. Back to the spring of Wuhan: facts and hope of covid-19 outbreak. Front Med. 2020. ahead of print.

3. Guan WJ, Ni ZY, Hu Y, Liang WH, Ou CQ, He JX, Liu L, Shan H, Lei CL, Hui DSC, Du B, Li LJ, Zeng G, Yuen KY, Chen RC, Tang CL, Wang T, Chen PY, Xiang J, Li SY, Wang JL, Liang ZJ, Peng YX, Wei L, Liu Y, Hu YH, Peng P, Wang JM, Liu JY, Chen Z, Li G, Zheng ZJ, Qiu SQ, Luo J, Ye CJ, Zhu SY, Zhong NS. China Medical Treatment Expert Group for C. Clinical characteristics of coronavirus disease 2019 in china. N Engl J Med. 2020.

4. Tang N, Bai H, Chen X, Gong J, Li D, Sun Z. Anticoagulant treatment is associated with decreased mortality in severe coronavirus disease 2019 patients with coagulopathy. J Thromb Haemost. 2020. ahead of print.

5. von Bahr V, Millar JE, Malfertheiner MV, Ki KK, Passmore MR, Bartnikowski N, Redd MA, Cavaye M, Suen JY, McAuley DF, Fraser JF. Mesenchymal stem cells may ameliorate inflammation in an ex vivo model of extracorporeal membrane oxygenation. Perfusion. 2019;34:15-21.

6. Abrams D, Ferguson ND, Brochard L, Fan E, Mercat A, Combes A, Pellegrino V, Schmidt M, Slutsky AS, Brodie D. ECMO for ARDS: from salvage to standard of care? Lancet Respir Med. 2019;7:108-10.

7. Fan E, Del Sorbo L, Goligher EC, et al. An official American Thoracic Society/ European Society of Intensive Care Medicine/Society of Critical Care Medicine clinical practice guideline: mechanical ventilation in adult patients with acute respiratory distress syndrome. Am J Respir Crit Care Med. 2017; 195:1253-63.

8. Abrams D, Fan E, Ferguson ND, Brodie D. Unproven and expensive may still be justifiable. Am J Respir Crit Care Med. 2018;198:140.

9. Combes A, Hajage D, Capellier G, Demoule A, Lavoué S, Guervilly C, et al. Extracorporeal membrane oxygenation for severe acute respiratory distress syndrome. N Engl J Med. 2018;378:1965-75.

10. Li M, Gu SC, Wu XJ, Xia JG, Zhang Y, Zhan QY. Extracorporeal membrane oxygenation support in 2019 novel coronavirus disease: indications, timing, and implementation. Chin Med J (Engl). 2020. ahead of print.

11. Bein T, Weber-Carstens S, Goldmann A, Müller T, Staudinger T, Brederlau J, et al. Lower tidal volume strategy $(\approx 3 \mathrm{ml} / \mathrm{kg}$ ) combined with extracorporeal CO2 removal versus 'conventional' protective ventilation $(6 \mathrm{ml} / \mathrm{kg})$ in severe ARDS: the prospective randomized Xtravent-study. Intensive Care Med. 2013;39:847-56

12. Rozencwajg S, Guihot A, Franchineau G, Lescroat M, Bréchot N, Hékimian G, et al. Ultra-protective ventilation reduces biotrauma in patients on venovenous extracorporeal membrane oxygenation for severe acute respiratory distress syndrome. Crit Care Med. 2019;47:1505-12.

13. Boyle AJ, Sklar MC, McNamee JJ, et al. Extracorporeal carbon dioxide removal for lowering the risk of mechanical ventilation: research questions and clinical potential for the future. Lancet Respir Med. 2018; 6:874-84. 
14. MacLaren G, Fisher D, Brodie D. Preparing for the most critically ill patients with COVID-19: the potential role of extracorporeal membrane oxygenation. J Am Med Assoc. 2020. ahead of print.

15. Ramanathan K, Antognini D, Combes A, Paden M, Zakhary B, Ogino M MacLaren G, Brodie D, Shekar K. Planning and provision of ECMO services for severe ARDS during the COVID-19 pandemic and other outbreaks of emerging infectious diseases. Lancet Respir Med. 2020. ahead of print.

16. Wang D, Hu B, Hu C, Zhu F, Liu X, Zhang J, Wang B, Xiang H, Cheng Z, Xiong Y, Zhao Y, Li Y, Wang X, Peng Z. Clinical characteristics of 138 hospitalized patients with 2019 novel coronavirus-infected pneumonia in Wuhan, China. J Am Med Assoc. 2020. ahead of print.

17. Tang X, Du R, Wang R, Cao T, Guan L, Yang C, Zhu Q, Hu M, Li X, Li Y, Liang L, Tong Z, Sun B, Peng P, Shi H. Comparison of hospitalized patients with acute respiratory distress syndrome caused by covid-19 and H1N1. Chest. 2020

18. Chousterman BG, Swirski FK, Weber GF. Cytokine storm and sepsis disease pathogenesis. Semin Immunopathol. 2017;39:517-28.

19. Broman LM, Prahl Wittberg L, Westlund CJ, Gilbers M, Perry da Camara L, Swol J, Taccone FS, Malfertheiner MV, Di Nardo M, Vercaemst L, Barrett NA, Pappalardo F, Belohlavek J, Muller T, Belliato M, Lorusso R. Pressure and flow properties of cannulae for extracorporeal membrane oxygenation I: return (arterial) cannulae. Perfusion. 2019:34:58-64.

20. Broman LM, Prahl Wittberg L, Westlund CJ, Gilbers M, Perry da Camara L, Westin J, Taccone FS, Malfertheiner MV, Di Nardo M, Swol J, Vercaemst L, Barrett NA, Pappalardo F, Belohlavek J, Muller T, Belliato M, Lorusso R. Pressure and flow properties of cannulae for extracorporeal membrane oxygenation II: drainage (venous) cannulae. Perfusion. 2019;34:65-73.

21. Malfertheiner MV, Pimenta LP, Bahr W, Millar JE, Obonyo NG, Suen JY, Pellegrino V, Fraser JF. Acquired von Willebrand syndrome in respiratory extracorporeal life support: a systematic review of the literature. Crit Care Resusc. 2017;19:45-52.

22. Tanaka KA, Bharadwaj S, Hasan S, Judd M, Abuelkasem E, Henderson RA, Chow JH, Williams B, Mazzeffi MA, Crimmins SD, Malinow AM. Elevated fibrinogen, von Willebrand factor, and factor VIII confer resistance to dilutional coagulopathy and activated protein $\mathrm{C}$ in normal pregnant women. Br J Anaesth. 2019;122:751-9.

23. Millar JE, Fanning JP, McDonald Cl, McAuley DF, Fraser JF. The inflammatory response to extracorporeal membrane oxygenation (ECMO): a review of the pathophysiology. Crit Care. 2016;20:387.

24. Ki KK, Passmore MR, Chan CHH, Malfertheiner MV, Bouquet M, Cho HJ, Suen $J Y$, Fraser JF. Effect of ex vivo extracorporeal membrane oxygenation flow dynamics on immune response. Perfusion. 2019;34:5-14.

25. Angus DC, van der Poll T. Severe sepsis and septic shock. N Engl J Med. 2013:369:840-51.

26. van der Poll T, Opal SM. Host-pathogen interactions in sepsis. Lancet Infect Dis. 2008;8:32-43.

27. Rimmer E, Houston BL, Kumar A, Abou-Setta AM, Friesen C, Marshall JC, Rock G, Turgeon AF, Cook DJ, Houston DS, Zarychanski R. The efficacy and safety of plasma exchange in patients with sepsis and septic shock: a systematic review and meta-analysis. Crit Care. 2014;18:699.

28. Mehta P, McAuley DF, Brown M, Sanchez E, Tattersall RS, Manson JJ, HIh Across Speciality Collaboration UK. Covid-19: consider cytokine storm syndromes and immunosuppression. Lancet. 2020;395:1033-1034.

29. Piacente C, Martucci G, Miceli V, Pavone G, Papeo A, Occhipinti G, Panarello G, Lorusso R, Tanaka K, Arcadipane A. A narrative review of antithrombin use during veno-venous extracorporeal membrane oxygenation in adults: rationale, current use, effects on anticoagulation, and outcomes. Perfusion. 2020:267659120913803. ahead of print.

30. Levy JH, Sniecinski RM, Welsby IJ, Levi M. Antithrombin: anti-inflammatory properties and clinical applications. Thromb Haemost. 2016;115:712-28.

31. Ruan $Q$, Yang K, Wang W, Jiang L, Song J. Clinical predictors of mortality due to COVID-19 based on an analysis of data of 150 patients from Wuhan, China. Intensive Care Med. 2020. ahead of print.

32. Zhou F, Yu T, Du R, Fan G, Liu Y, Liu Z, Xiang J, Wang Y, Song B, Gu X, Guan L, Wei Y, Li H, Wu X, Xu J, Tu S, Zhang Y, Chen H, Cao B. Clinical course and risk factors for mortality of adult inpatients with COVID-19 in Wuhan, China: a retrospective cohort study. Lancet. 2020;395:1054-62.

33. Kruttgen A, Rose-John S. Interleukin-6 in sepsis and capillary leakage syndrome. J Interf Cytokine Res. 2012;32:60-5.

34. Trager K, Schutz C, Fischer G, Schroder J, Skrabal C, Liebold A, Reinelt H. Cytokine reduction in the setting of an ARDS-associated inflammatory response with multiple organ failure. Case Rep Crit Care. 2016;2016:9852073.
35. Datzmann T, Trager K. Extracorporeal membrane oxygenation and cytokine adsorption. J Thorac Dis. 2018;10:S653-60.

36. Luo P, Liu Y, Qiu L, Liu X, Liu D, Li J. Tocilizumab treatment in covid-19: a single center experience. J Med Virol. 2020. ahead of print.

37. Michot JM, Albiges L, Chaput N, Saada V, Pommeret F, Griscelli F, Balleyguier C, Besse B, Marabelle A, Netzer F, Merad M, Robert C, Barlesi F, Gachot B, Stoclin A. Tocilizumab, an anti-IL6 receptor antibody, to treat COVID-19related respiratory failure: a case report. Ann Oncol. 2020. ahead of print.

38. Zhang C, Wu Z, Li JW, Zhao H, Wang GQ. The cytokine release syndrome (CRS) of severe COVID-19 and interleukin-6 receptor (IL-6R) antagonist tocilizumab may be the key to reduce the mortality. Int J Antimicrob Agents. 2020:105954. ahead of print.

39. Huang C, Wang Y, Li X, Ren L, Zhao J, Hu Y, Zhang L, Fan G, Xu J, Gu X, Cheng Z, Yu T, Xia J, Wei Y, Wu W, Xie X, Yin W, Li H, Liu M, Xiao Y, Gao H, Guo L, Xie J, Wang G, Jiang R, Gao Z, Jin Q, Wang J, Cao B. Clinical features of patients infected with 2019 novel coronavirus in Wuhan, China. Lancet. 2020;395:497-506.

40. Chang LM, Wei L, Xie L, Zhu G, Dela Cruz CS, Sharma L. Epidemiologic and clinical characteristics of novel coronavirus infections involving 13 patients outside Wuhan, China. JAMA. 2020. ahead of print.

41. Xu XW, Wu XX, Jiang XG, Xu KJ, Ying LJ, Ma CL, Li SB, Wang HY, Zhang S, Gao HN, Sheng JF, Cai HL, Qiu YQ, Li LJ. Clinical findings in a group of patients infected with the 2019 novel coronavirus (SARS-Cov-2) outside of Wuhan, China: retrospective case series. BMJ. 2020;368:m606.

42. Yin S, Huang M, Li D, Tang N. Difference of coagulation features between severe pneumonia induced by SARS-CoV2 and non-SARS-CoV2. J Thromb Thrombolysis. 2020. ahead of print

43. Behrens K, Alexander WS. Cytokine control of megakaryopoiesis. Growth Factors. 2018:36:89-103.

44. Qu R, Ling Y, Zhang YH, Wei LY, Chen X, Li XM, Liu XY, Liu HM, Guo Z, Ren $\mathrm{H}$, Wang Q. Platelet-to-lymphocyte ratio is associated with prognosis in patients with coronavirus disease-19. J Med Virol. 2020. ahead of print.

45. Fuchs G, Berg N, Broman LM, Prahl WL. Flow-induced platelet activation in components of the extracorporeal membrane oxygenation circuit. Sci Rep. 2018:8(1):13985.

46. Lippi G, Plebani M, Henry BM. Thrombocytopenia is associated with severe coronavirus disease 2019 (COVID-19) infections: a meta-analysis. Clin Chim Acta. 2020;506:145-8.

47. Thachil J, Tang N, Gando S, Falanga A, Cattaneo M, Levi M, Clark C, Iba T. ISTH interim guidance on recognition and management of coagulopathy in COVID-19. J Thromb Haemost. 2020. ahead of print.

48. Weingart C, Lubnow M, Philipp A, Bein T, Camboni D, Müller T. Comparison of coagulation parameters, anticoagulation, and need for transfusion in patients on interventional lung assist or veno-venous extracorporeal membrane oxygenation. Artif Organs. 2015;39(9):765-73.

49. Panigada M, Artoni A, Passamonti SM, Maino A, Mietto C, L'Acqua C, Cressoni M, Boscolo M, Tripodi A, Bucciarelli P, Gattinoni L, Martinelli I. Hemostasis changes during veno-venous extracorporeal membrane oxygenation for respiratory support in adults. Minerva Anestesiol. 2016;82(2):170-9.

50. Abrams D, Baldwin MR, Champion M, Agerstrand C, Eisenberger A, Bacchetta M, Brodie D. Thrombocytopenia and extracorporeal membrane oxygenation in adults with acute respiratory failure: a cohort study. Intensive Care Med. 2016;42(5):844-52.

51. Choi JH, Luc JGY, Weber MP, Reddy HG, Maynes EJ, Deb AK, Samuels LE, Morris RJ, Massey HT, Loforte A, Tchantchaleishvili V. Heparin-induced thrombocytopenia during extracorporeal life support: incidence, management and outcomes. Ann Cardiothorac Surg. 2019;8(1):19-31.

52. Haneya A, Philipp A, Diez C, Ried M, Puehler T, Camboni D, Zausig Y, Lehle K, Schmid C. Comparison of two different minimized extracorporeal circulation systems: hematological effects after coronary surgery. ASAIO J. 2009;55(6):592-7.

53. Balle CM, Jeppesen AN, Christensen S, Hvas AM. Platelet function during extracorporeal membrane oxygenation in adult patients: a systematic review. Front Cardiovasc Med. 2018;5:157.

54. Ludvigsson JF. Systematic review of covid-19 in children shows milder cases and a better prognosis than adults. Acta Paediatr. 2020. ahead of print.

55. Tan L, Wang Q, Zhang D, Ding J, Huang Q, Tang YQ, Wang Q, Miao H. Lymphopenia predicts disease severity of COVID-19: a descriptive and predictive study. Signal Transduct Target Ther. 2020;5:33.

56. Li T, Qiu Z, Zhang L, Han Y, He W, Liu Z, Ma X, Fan H, Lu W, Xie J, Wang H, Deng G, Wang A. Significant changes of peripheral T lymphocyte subsets in patients with severe acute respiratory syndrome. J Infect Dis. 2004;189:648-51. 
57. Ko JH, Park GE, Lee JY, Lee JY, Cho SY, Ha YE, Kang Cl, Kang JM, Kim YJ, Huh $\mathrm{HJ}$, Ki CS, Jeong BH, Park J, Chung CR, Chung DR, Song JH, Peck KR. Predictive factors for pneumonia development and progression to respiratory failure in MERS-CoV infected patients. J Inf Secur. 2016;73:468-75.

58. Wu C, Chen X, Cai Y, Xia J, Zhou X, Xu S, Huang H, Zhang L, Zhou X, Du C, Zhang Y, Song J, Wang S, Chao Y, Yang Z, Xu J, Zhou X, Chen D, Xiong W, Xu L, Zhou F, Jiang J, Bai C, Zheng J, Song Y. Risk factors associated with acute respiratory distress syndrome and death in patients with coronavirus disease 2019 pneumonia in Wuhan, China. JAMA Intern Med. 2020. ahead of print.

59. Chen G, Wu D, Guo W, Cao Y, Huang D, Wang H, Wang T, Zhang X, Chen $H$, Yu H, Zhang X, Zhang M, Wu S, Song J, Chen T, Han M, Li S, Luo X, Zhao J, Ning Q. Clinical and immunologic features in severe and moderate coronavirus disease 2019. J Clin Invest 2020. ahead of print.

60. Fina D, Matteucci M, Jiritano F, Meani $P$, Lo Coco V, Kowalewski M, Maessen J, Guazzi M, Ballotta A, Ranucci M, Lorusso R. Extracorporeal membrane oxygenation without therapeutic anticoagulation in adults: a systematic review of the current literature. Int J Artif Organs. 2020:391398820904372. ahead of print

61. Morrisette MJ, Zomp-Wiebe A, Bidwell KL, Dunn SP, Gelvin MG, Money DT, Palkimas S. Antithrombin supplementation in adult patients receiving extracorporeal membrane oxygenation. Perfusion. 2020:35:66-72.

62. Kalbhenn J, Wittau N, Schmutz A, Zieger B, Schmidt R. Identification of acquired coagulation disorders and effects of target-controlled coagulation factor substitution on the incidence and severity of spontaneous intracranial bleeding during veno-venous ecmo therapy. Perfusion. 2015:30:675-82.

63. Fisser C, Reichenbacher C, Muller T, Schneckenpointner R, Malfertheiner MV, Philipp A, Foltan M, Lunz D, Zeman F, Lubnow M. Incidence and risk factors for cannula-related venous thrombosis after venovenous extracorporeal membrane oxygenation in adult patients with acute respiratory failure. Crit Care Med. 2019;47:e332-9.

64. Oude Lansink-Hartgring A, de Vries AJ, Droogh JM, van den Bergh WM. Hemorrhagic complications during extracorporeal membrane oxygenation the role of anticoagulation and platelets. J Crit Care. 2019;54:239-43.

65. Chen N, Zhou M, Dong X, Qu J, Gong F, Han Y, Qiu Y, Wang J, Liu Y, Wei Y, Xia J, Yu T, Zhang X, Zhang L. Epidemiological and clinical characteristics of 99 cases of 2019 novel coronavirus pneumonia in Wuhan, China: a descriptive study. Lancet. 2020;395:507-13.

66. Liu K, Fang YY, Deng Y, Liu W, Wang MF, Ma JP, Xiao W, Wang YN, Zhong MH, Li CH, Li GC, Liu HG. Clinical characteristics of novel coronavirus cases in tertiary hospitals in Hubei province. Chin Med J. 2020. ahead of print.

67. Shen C, Wang Z, Zhao F, Yang Y, Li J, Yuan J, Wang F, Li D, Yang M, Xing L, Wei J, Xiao H, Yang Y, Qu J, Qing L, Chen L, Xu Z, Peng L, Li Y, Zheng H, Chen F, Huang K, Jiang Y, Liu D, Zhang Z, Liu Y, Liu L. Treatment of 5 critically ill patients with COVID-19 with convalescent plasma. JAMA. 2020 ahead of print.

68. Yang $X, Y u$ Y, Xu J, Shu H, Xia J, Liu H, Wu Y, Zhang L, Yu Z, Fang M, Yu T, Wang Y, Pan S, Zou X, Yuan S, Shang Y. Clinical course and outcomes of critically ill patients with SARS-CoV-2 pneumonia in Wuhan, China: a singlecentered, retrospective, observational study. Lancet Respir Med. 2020.

69. Clinical management of severe acute respiratory infection when novel coronavirus (nCov) infection is suspected. (https://www.who.int/ publications-detail/clinical-management-of-severe-acute-respiratoryinfection-when-novel-coronavirus-(ncov)-infection-is-suspected). Accessed 11 Apr 2020.

70. United States Center for Disease Control interim guidance for clinical management of COVID-19 patients with and without acute respiratory distress syndrome (https://www.cdc.gov/coronavirus/2019-ncov/hcp/clinicalguidance-management-patients.html). Accessed 11 Apr 2020

71. MacLaren G, Fisher D, Brodie D. Preparing for the most critically ill patients with COVID-19: the potential role of extracorporeal membrane oxygenation. JAMA. 2020. ahead of print.

72. Henry BM. COVID-19, ECMO, and lymphopenia: a word of caution. Lancet Respir Med. 2020;8:e24

73. EuroElso survey on ECMO use in adult COVID-19 patients in Europe https:// www.euroelso.net/covid-19/covid-19-survey. Accessed 11 Apr 2020.

\section{Publisher's Note}

Springer Nature remains neutral with regard to jurisdictional claims in published maps and institutional affiliations. 